INTERNATIONAL JOURNAL OF MULTIDISCIPLINARY RESEARCH AND ANALYSis

ISSN(print): 2643-9840, ISSN(online): 2643-9875

Volume 05 Issue 02 February 2022

DOI: 10.47191/ijmra/v5-i2-03, Impact Factor: 6.072

Page No.- 263-268

\title{
Information Technology Challenges of Family Planning and Reproductive Health During The Covid-19 Pandemic in Lebak District, Indonesia
}

\author{
Hariyanti \\ Department of Midwifery, Health Polytechnic Jakarta 1, Ministry of Health, Jakarta, Indonesia
}

ABSTRACT: During the COVID-19 pandemic, all activities are carried out online. One of them is the provision of information on Family Planning and Reproductive Health which must be provided to supervise family planning acceptors so that they do not experience discontinuation of contraceptive use. This study aimed to evaluate the provision of information on Family Planning and Reproductive Health provided online to the public. This study used a One-Shot Case Study design. The intervention given was the provision of contraceptive information through the WhatsApp group. The research sample was married women aged 15-49 years who used the pill and injection contraception in Lebak District. The number of samples in this study was 94 respondents. In this study, about $11 \%$ of married women stated that they had difficulty accessing contraceptive services during the COVID-19 pandemic. After being given information on Family Planning and Reproductive Health through WhatsApp groups, $66 \%$ of respondents stated that the intervention provided increased knowledge about contraception, $18 \%$ complained about the use of quotas, $6.4 \%$ stated that they could not understand because they were used to face-to-face. This study also explored information about suggestions for contraceptive service programs, namely $14.9 \%$ expects services and providing information on Family Planning and Reproductive Health to be carried out face-to-face and $12.8 \%$ recommended free contraceptive services. Conclusion. Providing information on Family Planning and Reproductive Health online is an alternative during the COVID-19 pandemic. However, during contraceptive services, health workers still directly provide information as needed. Information on payment for contraceptive services using health social security agency must be provided to acceptors and contraceptive service activities funded by the national family planning coordinating board must also be informed to increase the coverage of contraceptive use.

KEYWORDS: Information technology, family planning, contraception, covid-19

\section{INTRODUCTION}

The COVID-19 pandemic has not only reduced the number of contraceptive use in Indonesia, but most countries in the world have also experienced a decline in contraceptive use [1-3]. This is due to concerns about the spread of COVID-19 when they come to health facilities to get contraceptive services. People prefer not to go out of the house and limit access to contact with health workers or family planning officers as providers of contraceptive services and information on Family Planning and Reproductive Health. [4,5].

This decrease in contraceptive use has an impact on unwanted pregnancies. In low- and middle-income countries due to barriers accessing contraceptive services. it is estimated that an additional 49 million unmet need for modern contraception and 15 million unwanted pregnancies occur in a year [6]. In Indonesia, the number of unwanted pregnancies reaches 20.3\% [7]. Various efforts and policies have been set by the government to prevent a worse impact. The government urges to postpone pregnancy until the pandemic ends by using contraception that can be reached by every couple of childbearing age [8].

To overcome barriers in access to contraception and information services, digital health technology or information technology is a strategic step during the COVID-19 pandemic. Information technology can help contraceptive service providers maintain access to services or information to clients. This information technology can be in the form of text messages, telephone calls, websites, or applications that can be accessed independently by clients $[2,9]$.

Information technology can increase public knowledge, so people can protect themselves from unwanted pregnancies by using affordable contraception during the COVID-19 pandemic $[2,9,10]$. A large study reported a very useful application that functions 


\section{Information Technology Challenges of Family Planning and Reproductive Health During The Covid-19 Pandemic in Lebak District, Indonesia}

to coordinate the family planning community and identify countries that are at risk of shortages of contraceptive stocks then collaborate with suppliers and send them to these countries. Likewise, information is provided by the provider via telehealth so there is no direct contact. Complete information is provided regarding contraceptive methods, issuing prescriptions, screening using medical eligibility, and how to deal with side effects. through the ministries of health in Uganda, Madagascar, Congo, and Sinegal also collaborated to conduct DMPA-SC injection training independently through virtual [11].

In Indonesia, telehealth or telemedicine has developed which helps access health services, including contraceptive services. Telehealth or telemedicine is an urgent matter and a basic need during this covid-19 pandemic [12,13]. The government cooperates with cellular telecommunications service operators to support community activities using telecommunications services and telemedicine services [14], and in Indonesia, the number of internet and smartphone users is included in the top 10 in the world $[15,16]$.

Family planning and reproductive health information through an official website or online media before the pandemic period has been widely promoted and increased during this COVID-19 pandemic. The use of social media such as Instagram, Short Message Service, WhatsApp is effective in increasing communication access and has a positive impact on knowledge and behavior of the contraceptive use [17-19]. To further increase utilization and find out the right method of distributing information, this study aims to evaluate the results of online family planning and reproductive health information dissemination activities.

\section{METHOD AND MATERIAL}

This study uses a One-Shot Case Study design. The intervention was only given once, then immediately evaluated, namely the provision of contraceptive information through the WhatsApp group. The intervention was carried out for one month and then an evaluation related to the intervention. WhatsApp group consists of respondents, health cadres, and family planning officers. Family planning and reproductive health information are provided once a week. The material consists of family planning education e-books and flyers published by the national family planning coordinating board and the Ministry of Health. In the WhatsApp group, respondents can have discussions with health cadres or family planning officers. Discussions in WhatsApp groups are not limited in time within 24 hours.

The research sample was married women aged 15-49 years who used pills and injections in the work area of the Mandala Health Center and Cibadak Health Center, Lebak District. The number of samples in this study was 94 respondents. This research has obtained ethically appropriate information from the health ethics committee of the Health Polytechnic of Semarang, Ministry of Health with the number 269/EA/KEPK.2021.

\section{RESULT}

Table 1. The Overview of Contraceptive Services Access During the Covid-19 Pandemic Period in Lebak District in 2021

\begin{tabular}{|l|l|l|}
\hline Difficulty Accessing Contraceptive Services During the Covid-19 Pandemic & $\mathrm{n}$ & $\%$ \\
\hline Yes & 84 & 89.4 \\
\hline No & 10 & 10.6 \\
\hline Total & 94 & 100.0 \\
\hline
\end{tabular}

Table 1 shows that around 11\% of married women aged 15-49 years find it difficult to access contraceptive services during the covid-19 pandemic.

Table 2. The Overview of Benefits Providing Family Planning and Reproductive Health Information through Whatsapp Groups during the Pandemic in Lebak District in 2021

\begin{tabular}{|c|c|c|}
\hline The Benefits of providing family planning and reproductive health information through Whatsapp group & $\mathrm{n}$ & $\%$ \\
\hline Increase knowledge & 62 & 66.0 \\
\hline fast response and easy access & 5 & 5.3 \\
\hline Can be done while doing homework & 3 & 3.2 \\
\hline Can be read many times, anytime, and as a reminder for family planning & 5 & 5.3 \\
\hline Complete and detailed answer & 6 & 6.4 \\
\hline As a discussion room & 6 & 6.4 \\
\hline No crowd & 7 & 7.4 \\
\hline Total & 94 & 100,0 \\
\hline
\end{tabular}




\section{Information Technology Challenges of Family Planning and Reproductive Health During The Covid-19 Pandemic in Lebak District, Indonesia}

Table 2 shows that the benefits felt by married women on family planning and reproductive health information provided through WhatsApp groups are mostly stated that they increase knowledge (66\%), and prevent crowds so that COVID-19 transmission does not occur (7.4\%). Respondents also stated that in providing information through the WhatsApp group, the officers responded quickly, the information provided was complete, and could discuss the family planning issues they were facing, and most importantly as a reminder to repeat family planning.

Table 3. The Overview of the Limitations Providing Family Planning and Reproductive Health Information through Whatsapp Groups during the Pandemic in Lebak District in 2021

\begin{tabular}{|l|l|l|}
\hline $\begin{array}{l}\text { The Lack of information on family planning and reproductive health } \\
\text { information through Whatsapp groups }\end{array}$ & $\mathrm{n}$ & $\%$ \\
\hline Requires quota & 17 & 18.1 \\
\hline Don't always hold the cellphone so it's late to read WA & 3 & 3.2 \\
\hline Signal problem & 4 & 4.3 \\
\hline Less understandable because they are used to face-to-face & 6 & 6.4 \\
\hline link can't be opened & 2 & 2.1 \\
\hline Saying there is no shortage & 62 & 66.0 \\
\hline Total & 94 & 100.0 \\
\hline
\end{tabular}

Table 3. Shows a lack of providing family planning and reproductive health information through WhatsApp groups, most respondents complained about needing a quota to access the information provided (18.1\%). Respondents also said they could not understand because they were used to face-to-face (6.4\%), and signal problems were also a drawback in this online activity.

Table 4. Recommendations for Contraception and Information Services during the Pandemic Period in Lebak District in 2021

\begin{tabular}{|l|l|l|}
\hline Suggestions for contraceptive services and information & $\mathrm{n}$ & $\%$ \\
\hline Continue to provide contraceptive services and direct information & 14 & 14.9 \\
\hline Free contraceptive services & 12 & 12.8 \\
\hline Not giving advice & 68 & 72.3 \\
\hline Total & 94 & 100,0 \\
\hline
\end{tabular}

Table 4 shows the recommendations given by married women for contraceptive and information services during the covid-19 pandemic, which is about $15 \%$ of married women suggesting that providers continue to carry out direct contraceptive and information services as before the covid-19 pandemic occurred. The next recommendation is for providers to make contraceptive services free (12.8\%).

\section{DISCUSSION}

The findings of this study are around $11 \%$ of married women have difficulty accessing contraceptive services during the COVID19 pandemic. The intervention carried out in this study was able to increase respondents' knowledge about family planning and reproductive health. However, there are still obstacles in implementing online interventions, namely a need to prepare quotas to access information provided online, and often have signal problems, and have to adapt communicating without face-to-face which causes people to not understand the information conveyed.

Access to contraceptive services has been affected by the COVID-19 pandemic in almost all countries [1,3,20]. The COVID-19 pandemic requires restrictions on all activities, including family planning and reproductive health services [10]. UNFPA estimates that 12 million women in 115 low- and middle-income countries are unable to access family planning services as a result of the COVID-19 pandemic, which has resulted in 1.4 million unwanted pregnancies [21]. In Indonesia, unwanted pregnancies reached $20.3 \%$ [7].

Efforts to ensure that family planning acceptors do not experience discontinuation of contraception and invite married women to use contraception during the COVID-19 pandemic are through telehealth or telemedicine. Family planning counselors and 


\section{Information Technology Challenges of Family Planning and Reproductive Health During The Covid-19 Pandemic in Lebak District, Indonesia}

health workers must be able to take advantage of this information technology. With the help of information technology, family planning officers can provide services whenever needed [22].

Indonesia is currently developing community-based telemedicine that can reach the entire community. Through the Ministry of Health, Indonesia is trying to develop a telemedicine platform to open the widest possible access to safe, comfortable, and quality health services for all citizens. This program is called SehatPedia [23]. Although Indonesia has a society with internet access and the most smartphone users, in remote areas there are still groups of people who do not have internet access. In addition, from a social and cultural perspective, especially in a community that has close family relationships, there are still many clients who prefer face-to-face consultations. The socio-cultural shift from traditional consultation to teleconsultation will take time, especially in rural and remote areas. Therefore, most of the teleconsultation of family planning officers and clients is mostly used by urban communities [24].

Internet use requires a quota that must be purchased by the public to access the internet. Meanwhile, the COVID-19 pandemic has had a major impact on the people's economy, which has reduced people's purchasing power, including internet quotas [25]. Currently, internet quota assistance is provided by the government to help distance education provided by the Ministry of Education and Culture to students, university students, and educators. [26]. This is a challenge that needs to be solved by the government by cooperating with the private sector.

This study also revealed that some people expect direct contraceptive services. According to the guidelines for family planning and reproductive health services during the COVID-19 pandemic, it is stated that face-to-face meetings can still be carried out by implementing health protocols and for clients who have complaints or are unable to use contraception without helping of family planning officers. [8].

The next recommendation based on the results of this study is that the community hopes that contraceptive services are free of charge. This needs to be socialized by family planning officers that the cost of contraceptive services is borne by the government, and the national family planning coordinating board is committed to making contraceptive services free during this COVID-19 pandemic. [27].

\section{CONCLUSIONS}

Based on the findings of this research, the challenges of family planning and reproductive health information technology in Indonesia are that first, Indonesia has remote areas that are difficult to access the internet and there is a social-cultural perspective that is reluctant to use the internet; second is high poverty rate which affects the purchasing power of people, including the purchase of internet quota.

Contraceptive services are prioritized to be carried out online but can be done directly by coming to the provider by implementing health protocols and is intended for people who have complaints or are not able to use contraception without helping of family planning officers. Officers need to inform the public about the cost of contraception that can be claimed by the Health Social Security Agency and free contraception from the national family planning coordinating board.

\section{ACKNOWLEDGMENT}

I would like to thank the Health Polytechnic Jakarta I for providing support and research funding so that this research was completed on time. The authors thank all participants and research assistants.

\section{REFERENCES}

1) Witono, Parwodiwiyono S. Kepesertaan Keluarga Berencana Pada Masa Awal Pandemi Covid-19 di Daerah Istimewa Yogyakarta. Kependudukan, Keluarga, Dan Sumber Daya Mns 2020;1:77-88. https://doi.org/10.37269/pancanaka.v1i2.47.

2) Habib M, Ludwig S, Lange U, da Costa CP. The impact of the COVID-19 pandemic on pregnancy, birth and sexual \& reproductive health and rights: Perspectives from Germany and Somalia. J Glob Health 2021;11:1-4. https://doi.org/10.7189/jogh.11.03085.

3) USAID. The Effects of Covid-19 on Sexual and Reproduction Health: A Case Study of Six Countries. 2021. https://doi.org/10.31826/9781463236984-toc.

4) Ndayara PM. Determinants of Contraceptive Method Choice in Kenya. 2016.

5) Alimoeso S. Memperkuat Pemakaian Kontrasepsi, Menjaga Bonus Demografi. BkkbnGold 2020. https://www.bkkbn.go.id/detailpost/memperkuat-pemakaian-kontrasepsi-menjaga-bonus-demografi(accessed January 8, 2022). 


\section{Information Technology Challenges of Family Planning and Reproductive Health During The Covid-19 Pandemic in Lebak District, Indonesia}

6) Puri MC, Stone L. Potential Impact of the COVID-19 Pandemic on Sexual and Reproductive Health in Nepal. J Nepal Health Res Counc 2020;18:313-5. https://doi.org/10.33314/jnhrc.v18i2.2747.

7) BKKBN. Tingkatkan Capaian Pelayanan KB, OPD-KB Kabupaten/Kota Lakukan MoU Dengan Fasilitas Kesehatan. BkkbnGold 2021.

https://www.bkkbn.go.id/detailpost/tingkatkan-capaian-pelayanan-kb-opd-kb-kabupaten-kota-lakukan-mou-denganfasilitas-kesehatan (accessed January 8, 2022).

8) Kementerian Kesehatan Republik Indonesia. Panduan Keluarga Berencana Dan Kesehatan Reproduksi Dalam Situasi Covid 19. vol. 1. 2020.

9) WHO. Providing Family Planning Services During an Epidemic. 2021.

10) Kemenkes RI. Protokol Petunjuk Praktis Layanan Kesehatan Ibu dan Bayi Baru Lahir Selama Pandemi CoVID-19. Protok Gugus Tugas Percepatan Penanganan Covid-19 Ri 2020;4:1-11.

11) Mickler AK, Carrasco MA, Raney L, Sharma V, May A V., Greaney J. Applications of the High Impact Practices in Family Planning during COVID-19. Sex Reprod Heal Matters 2021;29. https://doi.org/10.1080/26410397.2021.1881210.

12) Israwati. Telehealth Pada Masa Pandemi Covid-19: Literatur Review. UNIVERSITAS ISLAM NEGERI ALAUDDIN MAKASSAR, 2021.

13) Wantiknas. Solusi Telemedicine di Tengah Pandemi. Wantiknas 2020:1-59.

14) RI KK dan I. Dukung Telemedicine, Kominfo Gandeng Operator Seluler Jaga Kualitas Layanan. KominfoGold 2021. https://www.kominfo.go.id/content/detail/35541/dukung-telemedicine-kominfo-gandeng-operator-seluler-jagakualitas-layanan/0/berita_satker (accessed January 14, 2022).

15) Hidayat W. Pengguna Internet Indonesia Nomor Enam Dunia. KominfoGold 2014.

https://kominfo.go.id/content/detail/4286/pengguna-internet-indonesia-nomor-enam-dunia/0/sorotan_media (accessed January 8, 2022).

16) Pusparisa Y. Daftar Negara Pengguna Smartphone Terbanyak, Indonesia Urutan Berapa? Https://DataboksKatadataCold/2021. https://databoks.katadata.co.id/datapublish/2021/07/01/daftar-negarapengguna-smartphone-terbanyak-indonesia-urutan-berapa (accessed January 8, 2022).

17) Tasya Z, Yani A. Pengaruh Media SMS Reminder Terhadap Pengetahuan Suami Tentang Vasektomi Di Puskesmas Parigi Kabupaten Parigi Moutong. MPPKI (Media Publ Promosi Kesehat Indones Indones J Heal Promot 2019;2:51-5. https://doi.org/10.31934/mppki.v2i1.528.

18) Kusuma Inggar D. Optimalisasi Promosi Kesehatan Reproduksi Melalui Jeraring Media Sosial (Narative Review). J lakmi 2020:1-7.

19) Nuryati S, Yanti RD. Efektifitas Penggunaan Media Sosial Terhadap Peningkatan Pada Ibu Nifas Di Kota Bogor. Midwife J 2017;3:52-9.

20) Roy N, Amin MB, Maliha, Maskura Jahan Sarker B, Aktarujjaman M, Hossain E, Talukdar G. Prevalence and factors associated with family planning during COVID-19 pandemic in Bangladesh: A cross-sectional study. PLoS One 2021;9:114.

21) UNFP. Impact of COVID-19 on Family Planning : What we know one year into the pandemic. United Nations Popul Fund 2021:1-9.

22) Haksoro A. BKKBN Minta Penyuluh KB Manfaatkan Teknologi Informasi. GatraCom 2019. https://www.gatra.com/news455668-kesehatan-bkkbn-minta-penyuluh-kb-manfaatkan-teknologi-informasi.html (accessed January 12, 2022).

23) Kementerian Kesehatan Republik Indonesia. Indonesia dan Inggris gelar Lokakarya Telemedicine Berbasis Komunitas. KemkesGold2020.https://www.kemkes.go.id/article/view/20110500009/indonesia-dan-inggris-gelar-lokakaryatelemedicine-berbasis-komunitas.html (accessed January 14, 2022).

24) Mawuntu AHP. Telekonsultasi medis meningkat pesat saat pandemi COVID-19, tapi muncul tiga masalah baru. Convert 2020.https://theconversation.com/telekonsultasi-medis-meningkat-pesat-saat-pandemi-covid-19-tapi-muncul-tigamasalah-baru-140228 (accessed January 14, 2022).

25) Sayuti RH, Hidayati SA. Dampak Pandemi Covid-19 Terhadap Ekonomi Masyarakat di Nusa Tenggara Barat. RESIPROKAL J Ris Sosiol Progresif Aktual 2020;2:133-50. https://doi.org/10.29303/resiprokal.v2i2.46.

26) Pengelola Web Kemdikbud. Kemendikbud Resmikan Kebijakan Bantuan Kuota Data Internet 2020. KemdikbudGold 2020.https://www.kemdikbud.go.id/main/blog/2020/09/kemendikbud-resmikan-kebijakan-bantuan-kuota-datainternet-2020 (accessed January 15, 2022). 
Information Technology Challenges of Family Planning and Reproductive Health During The Covid-19 Pandemic in Lebak District, Indonesia

27) BKKBN. Hasto Wardoyo : BKKBN Sediakan Obat Kontrasepsi Gratis. BkkbnGold 2021.

https://www.bkkbn.go.id/detailpost/hasto-wardoyo-bkkbn-sediakan-obat-kontrasepsi-gratis (accessed January 16, 2022). 